PEREGRINE FALCON HARASSES SANDHILL CRANES IN FLIGHT

In late afternoon on 3 May 1975, Herb Copland, Spencer Sealy and I observed a Peregrine Falcon harassing a group of three pairs of Sandhill Cranes. This was about $8 \mathrm{~km}$ ( $5 \mathrm{mi}$.) south of East Braintree in extreme southeastern Manitoba. When first seen, the cranes were alternately flapping and soaring high overhead, heading southwest. Suddenly a Peregrine Falcon appeared, rapidly gained on the group and then flew amongst them, whereupon the cranes separated somewhat, though still keeping in pairs. When the Peregrine flew close behind one crane, it veered away from the others, sideslipping and flying rapidly with the Peregrine right behind it. It looked as if the Peregrine intended to attack, but it shortly broke off the chase and flew away. The lone crane soon joined its mate and the six birds continued on their leisurely flight. This spectacular aerial event lasted perhaps two or three minutes.

Playful pursuit by the Peregrine Falcon of large birds has been reported a few times. Alexander Wetmore, for example, in 1933 (in Bent, A.C., 1938, Life histories of North American birds of prey, Part 2, Dover Publ., New York, reprint 1961) describes a Peregrine Falcon pursuing Black-crowned Night-Herons as they flushed before his boat along a river. The Peregrine repeatedly flew at individual herons until each was forced into the water and had to swim ashore. In a review of major publications on the Peregrine Falcon and the Sandhill Crane, however, I found no reference to interactions between these two species. Robert W. Nero, Box 14, 1495 St. James Street, Winnipeg, Manitoba. R3H OW9

\section{FIRST BAND-TAILED PIGEON IN YORKTON AREA}

JOYCE ANAKA, Box 211, Yorkton, Saskatchewan. S3N 2V7

On 28 August 1985 I had the birding highlight of the summer. As I walked out to look at Good Spirit Lake from the south shore a large, unfamiliar, pigeonlike bird landed on top of a dead tree 50 $\mathrm{ft}$. away. For approximately 5 minutes I watched it through $8 \times 10$ binoculars while it watched me with interest - head weaving and bobbing.

While observing it I jotted down its characteristics on a piece of paper I had in my pocket. The most obvious were the black-tipped, yellow beak, red eyes and yellow feet. There was a white strip behind the eye and a very dark, almost black area behind the white strip. The body was an overall very pale light brown with a hint of darker color in the wings but no wing marks, bars or other marks other than those noted on the nape of the neck and head.

I drew a rough sketch of it before it flew off. It went about 100 yards west along the lake bank and again landed on a dead tree. I went to pick up the camera but before I could get into range the bird flew off to the south. I checked the area but could not locate it again.

With the aid of my sketch and notes on field marks Bill identified the bird as a Band-tailed Pigeon. This is the first hypothetical record of this species for this part of Saskatchewan. 